\title{
CONSTANTINE THE GREAT AND AQUILEIA: A NEW HOARD EVIDENCE
}

\begin{abstract}
This contribution is dedicated to a small hoard of Constantinian nummi found in Aquileia in the early ' 60 s, but only recently "rediscovered" in the coin cabinet of the National Museum. 20 of the 21 coins belong to the same issue type VIRT EXERCIT, struck in AD 319 in Thessalonica, specifically conceived for the distribution to the troops and rarely attested among treasure and single finds of the entire Mediterranean area. Within the assemblage, three die-linked specimens have been detected as well as an obverse brockage coin, peculiar features proper to a uniform stock of coins concealed soon after its production. During the struggle for power against Licinius, Constantine the Great visited many times Aquileia between 318 and $319 \mathrm{AD}$ as attested by ancient sources. Given the peculiar traits of the hoard, the owner should be sought among the members of the Constantinian army, following the emperor or involved in supply duties, frequently moving between Northern Italy and the Balkans during the war against the Licinian dynasty. Keywords: Aquileia, Thessalonica, Constantine the Great, Licinius I, Roman army.
\end{abstract}

\section{INTRODUCTION}

D uring the Late Roman age, the former Latin colony of Aquileia reached its height, also as logistic center for the Roman army stationed on the Danubian limes $^{1}$. As a consequence, the city was the scenario of many of the most pivotal military events of the period and was frequently elected as the headquarter of usurpers and legitimate emperors. One of them paid particular attention to Aquileia during his entire reign: Constantine the Great. Now, a new evidence concerning his stays and the presence of his comitatus in the city is available thanks to the very recent re-examination of a hoard find.

\section{THE HOARD}

The content of the hoard, found by chance, was acqui-

\footnotetext{
1 For an historical overview of Aquileia during the late Roman age see MARANO 2009.
}

\section{Andrea Stella}

University of Padua, department of Cultural Heritage

andrea.stella86@gmail.com

DOI: $10.14795 /$ j.v7i1_SI.495

ISSN 2360 - 266X

ISSN-L 2360 - 266X 


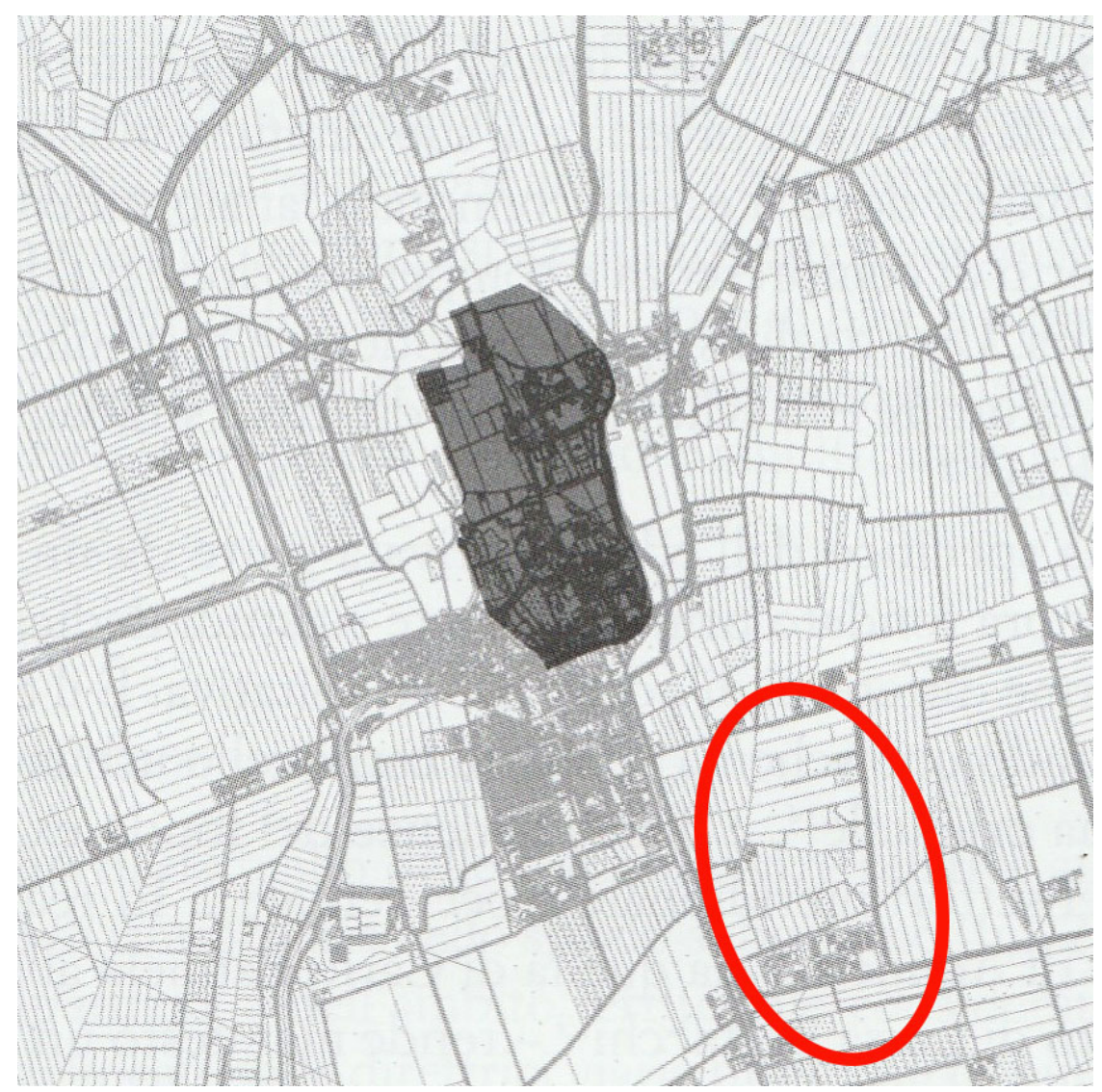

Pic. 1. The sourthern suburbium of Aquileia and the area (red circle) in which the findspot of the Beligna hoard could be placed. After MAGGI/ORIOLO 2012, 409, pic. 1 (modified).

red in the early '60s by the National Museum of Aquileia thanks to Luisa Bertacchi, head of the Museum between 1959 and 1989². Little is known about the findspot, generically located to the south of the ancient city and east of the modern road leading to Grado, an area denominated "Beligna" ${ }^{3}$ (Pic. 1 ). The origin of the name seems to derive from the celtic deity Belenus, one of the prominent civic cults in the Roman Aquileia ${ }^{4}$, to whom a place of worship was dedicated in the same place ${ }^{5}$. Beligna was also the greatest burial site of the city employed between the end of the $1^{\text {st }}$ century $\mathrm{BC}$ and $5^{\text {th }}$ century $\mathrm{AD}$, and maybe beyond ${ }^{6}$.

\footnotetext{
2 On Luisa Bertacchi and her contribution to the development of the coin cabinet of the National Museum in Aquileia see GORINI 2015; STELLA 2019a, 5-8.

3 For an historical and archaeological summary of Beligna see BUORA 1979.

4 On the cult of Belenus in Aquileia and Northern Italy see ZACCARIA 2008 with further bibliography.

5 FONTANA 1997, 153-155; VERZAR-BASS 2000, 149-151.
}

6 For a survey of the archaeological and epigraphical
In respect to this, no evidence are available to reconnect the hoard to a grave good since no data on the archaeological context are known. It apparently consists of 21 nummi; there is no certainty about the entirety of the content even if its peculiarity, as discussed below, could be a proof of completeness (Tab. 1). Surely the coins included were originally stacked together, as demonstrated by corrosion layers before cleaning operations, inside a container, possibly made of perishable material, of which no traces are preserved (Pic. 2). Furthermore, for some specimens in good condition, the restoration process unveiled the surface of the nummi showing the original silver wash ${ }^{7}$.

Previously the hoard, or more specifically a purse, was only briefly mentioned in the literature but never analyzed in depth $^{8}$. A new recent overview of the late Roman monetary circulation in Aquileia, mostly based on data drawn from an unrecorded section of the local coin cabinet, gave

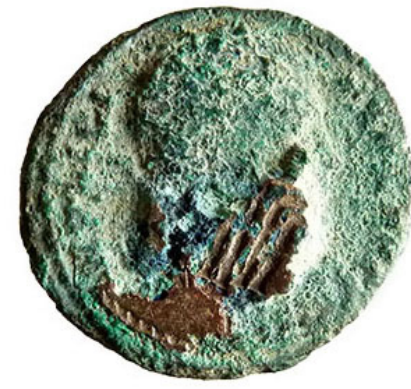

Pic. 2 A coin from the Beligna hoard showing traces of the original piling. After STELLA 2019b, 58, pic. 16 .

evidences of the late Roman burial sites in Aquileia see GIOVANNINI 2012-2013.

7 Recent investigations on the nummi from the great Misurata hoard shed new light on this manufacturing process; CILIBERTO/VISCUSO 2015; FERRETTI/ GUIDA/LASCHERA/MANDA 2015.

8 BERTACCHI 1968, 179, nn. 38-58; GORINI 1984, 289. 
Tab. 1. Composition of the Beligna hoard.

\begin{tabular}{|c|c|c|c|c|c|}
\hline Authority & Person & N. of specimens & $\begin{array}{l}\text { Mint } \\
\text { mark }\end{array}$ & Reference & Notes \\
\hline Constantine I & Constantine I & 6 & •TS•Г• & RIC 66 & \\
\hline Licinius I & Licinius I & 3 & $\cdot \mathrm{TS} \cdot \mathrm{A} \cdot$ & RIC 68 & \\
\hline Constantine I & Crispus & 7 & $\cdot \mathrm{TS} \cdot \mathrm{C} \cdot$ & RIC 69 var. & $\begin{array}{l}\text { The obverse bust appears to be also } \\
\text { draped and not only cuirassed; cfr. } \\
\text { BRENOT } 1968,89, \text { ns } 155-158 \text {. }\end{array}$ \\
\hline Constantine I & Constantine II & 4 & $\cdot \mathrm{TS} \cdot \mathrm{B} \cdot$ & RIC 71 & \\
\hline Constantine I & Constantine II & 1 & / & RIC? & $\begin{array}{c}\text { On the ground of style, the coin can } \\
\text { be attributed to the mint of Ticinum/ } \\
\text { Aquileia. }\end{array}$ \\
\hline
\end{tabular}

the chance for a complete re-assessment of the find which revealed its importance under the numismatic and historical perspective ${ }^{9}$.

A first peculiar feature is to be found in the composition; in fact 20 of the 21 nummi belong to the same issue struck in the mint of Thessalonica in $319 \mathrm{AD}$. On the reverse it bears the legend VIRT EXERC and the type of Sol standing on what was recognized to be the plan of a military $\operatorname{camp}^{10}$ (Pic. 3). This description, gave by Patrick Bruun in RIC, is based on the interpretation proposed before by Maurice $^{11}$. According to an alternative hypothesis, in this typology could be seen the representation of the radiate cross appeared in a dream to Constantine in $310 \mathrm{AD}$, as attested by literary sources ${ }^{12}$. Despite the different interpretations gave, this issue surely constitutes one of the last representation of Sol on the Constantinian coinage ${ }^{13}$.
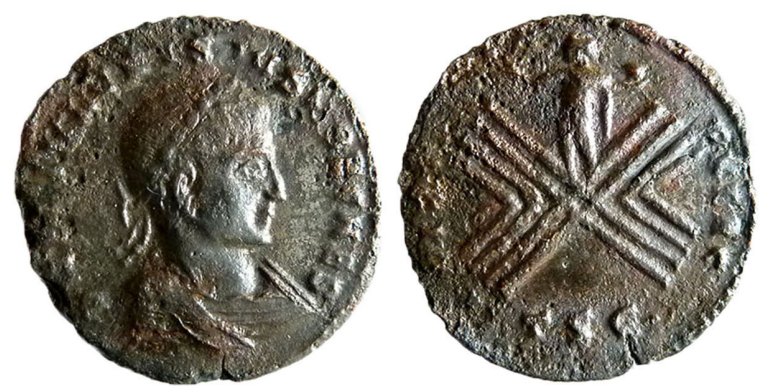

Pic.3. A specimen of the type VIRT EXERCIT from the Beligna hoard. After STELLA 2019b, cat. n. 3/B/14.

\footnotetext{
9 STELLA 2019b, 57-61.

10 RIC, VII, nn. 66-71.

11 MAURICE 1911, 447.

12 BRENOT 1968, 84; WEISS 2003, 251.

13 BRUUN 1991a.
}

Other than the intriguing iconography, the coins type VIRT EXERC belong to a very limited issue rarely attested among single and hoard finds, as demonstrated by a search, without the completeness assumption, in the available literature. The large Bikić-Do hoard found near Sremska Mitrovica/Sirmium is, apparently, the only treasure to feature a considerable amount of coins of this kind, 6 specimens out of more than 1700 coins produced in Thessalonica ${ }^{14}$. Unfortunately, the absence of a detailed edition of many hoard finds, especially those from the Balkan area listed by Mirnik ${ }^{15}$, doesn't allow a further overview on the distribution of this coin type. The trend among single finds doesn't change. On the one hand, thanks to the database of the Portable Antiquities Scheme, a very few data are known for England ${ }^{16}$. On the other, no further specimens are known so far among site finds in the Mediterranean area. What strikes most is the complete absence from the great assemblages belonging to sites in which the output of Thessalonica played an important role in the monetary supply; that's the case for Carnuntum $^{17}$, the Athenian agora ${ }^{18}$ and the area

\footnotetext{
14 BRENOT 1968 already cited on note 12. It was not possible to evaluate the possible presence of the issue in another great treasure of nummi, the Misurata hoard 15 MIRNIK 1981.

16 https://finds.org.uk/. Accessed 6 August 2019: NCLD720B2, Crispus, var. TSE, RIC 69; SUSS-899073, Constantine I, RIC 67; HAMP-84EAF0, Licinius I, RIC 68. 17 FMRÖ III/2.

18 THOMPSON 1954.
} 

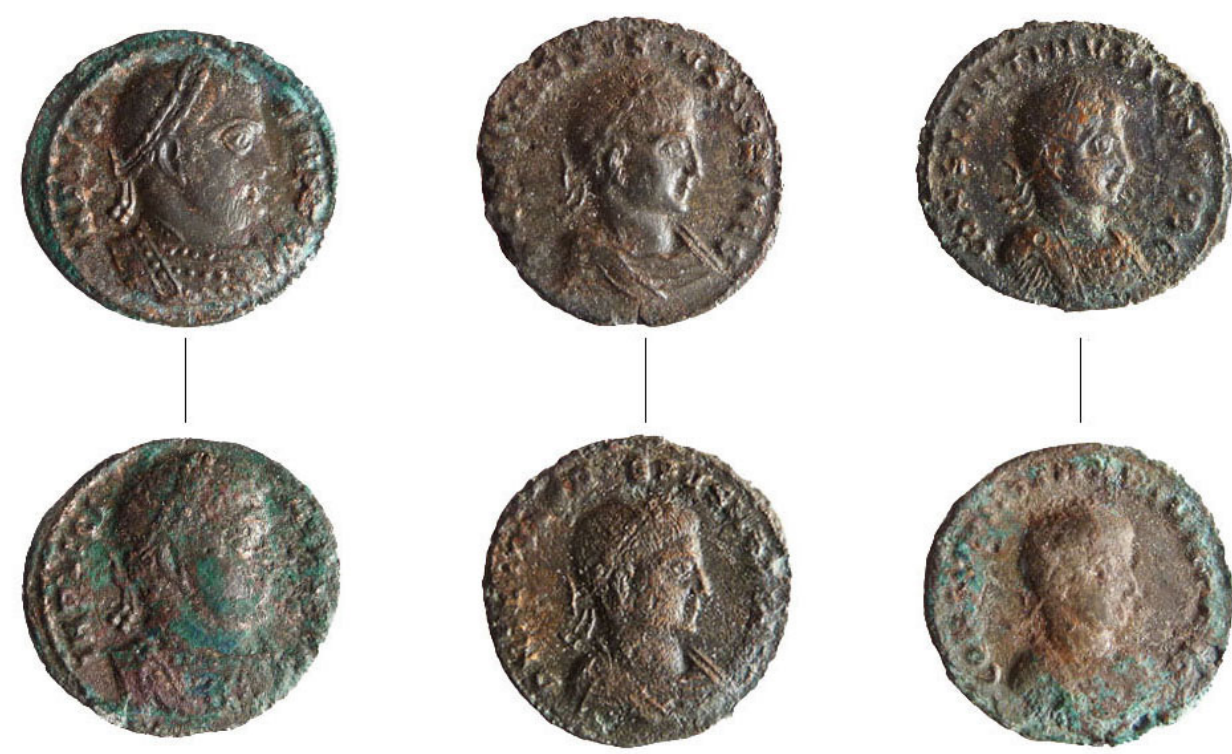

nummus of Constantine $\mathrm{II}^{21}$ (Pic. 5). This coin stylistically differs from the others. It could belong to another mint, an Italian one (Ticinum/Aquileia?), and maybe to the vota coinage of the early 20's; this chronology could reflect the date of concealment as well ${ }^{22}$. Nevertheless, this presence doesn't seem to Constantine II. After STELLA 2019b, 60, pic. 18 (modified).

of modern Serbia ${ }^{19}$. Also numismatic auctions have been considered ${ }^{20}$. In the light of this overview, the 20 coins of the small hoard from Beligna constitutes, in all respects, one of the greatest documentation available for the type VIRT EXERCIT. Furthermore, the high degree of rarity of the coins belonging to this issue is the evidence of a small-scale production, possibly conceived for a distribution limited to special occasions.

A closer inspection to the content, thanks to a complete restoration process, revealed further unique aspects. First of all, it was possible to observe 3 die-linked obverse die pairs (Pic. 4); additional matchings have not been detected due to the poor state of preservation of many of the coins. But the most impressive discovery regards an obverse brockage

19 No specimens are recorded in the coin cabinet of the National Museum of Belgrade. I would like to thank Tatjana Bendžarević, Mirjana Vojvoda and Cristian Găzdac for helping me in the search of further specimens among sites of Serbia and the Danubian limes in general.

20 Source: https://www.acsearch.info/. Accessed 6 August 2019: Numismatik Naumann, Auction 41(2016), Lot 900, Constantine I, RIC 66; Baldwin's Auctions Ltd, Winter Argentum Auctions (2016), Lot 46, Constantine I, RIC 66; Classical Numismatic Group, Electronic Auction 402 (2017), Lot 569, Constantine I, RIC 66; Numismatik Naumann, Auction 58(2017), Lot 567, Constantine I, RIC 66; Agorà Auctions, Sale 71 (2017), Lot 309, Constantine II, RIC 71. significantly alter the global structure of the hoard, a uniform stock of coins, almost entirely belonging to the same issue, concealed soon after its production and without an intermediate circulation.

Therefore, thanks to a very wide set of
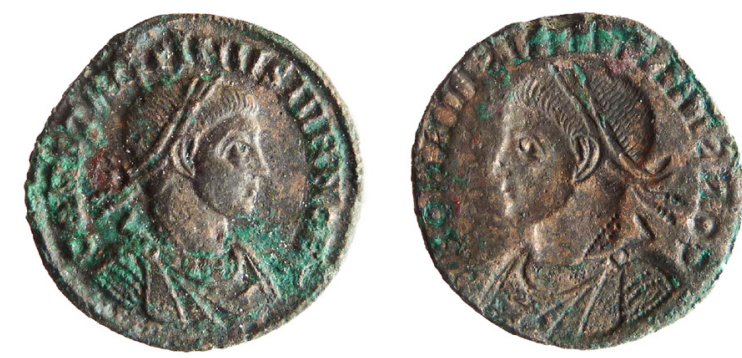

Pic. 5. The obverse brockage nummus of Constantine II, mint of Ticinum/Aquileia (?). After STELLA 2019b, 60, pic. 19.

distinctive numismatic features is possible to define the circumstances in which the hoard was deposited, including the potential owner, with a high degree of certainty. However, since the historical background as well plays a decisive role it has to be closely analyzed.

${ }^{21}$ On brockage coins see NURPETLIAN 2018.

22 Cfr. RIC, VII, Ticinum, ns 154, 162, 166, 172; Aquileia, ns 76, 79, 113. In STELLA 2019b, cat. n. 21 the coin is attributed to the mint Thessalonica, like the other specimens of the hoard. A further investigation suggested this new attribution. 


\section{CONSTANTINE IN AQUILEIA: THE HISTORICAL BACKGROUND AND THE NUMISMATIC EVIDENCE}

The chronological segment of interest, in which the date of concealment must be placed, corresponds to the break between the first and the second Civil War (316/317$323 / 324 \mathrm{AD})^{23}$. Already at the beginning of the hostilities, Northern Italy was a strategic ground for Constantine (Tab. 2). He planned and started in Verona his march against Licinius towards the Balkans, culminated in the battle of Cibalae at the end of $316 \mathrm{AD}$, while the presence of the defensive system of Claustra Alpium Iuliarum ${ }^{24}$ would have prevented a potential invasion of Italy by Licinius ${ }^{25}$. As a consequence of the Bellum Cibalense, Constantine permanently expanded his dominion over the Balkans, with the exception of the Diocesis Thraciae, establishing his headquarter, alternately, between Sirmium and Serdica in particular, and Thessalonica ${ }^{26}$. From 313 to 323 AD he left the Balkan area just one time for a journey to Northern Italy. In this occasion he paid visit to Aquileia several times during $\mathrm{AD} 318$, as attested by the laws promulgated there according to the Codex Theodosianus and the production of the local mint ${ }^{27}$. A gold issue celebrating the processus consularis marks the presence of the emperor in the city even at the beginning of AD $319^{28}$. Later that year, once Constantine has reached Sirmium, the imperial court is still attested in Ticinum $^{29}$. The emperor paid great attention also to the maintenance of the road system of the area as witnessed by the milestones placed on the road between Mediolanum and Aquileia in the years $312 / 315-324 \mathrm{AD}^{30}$.

As demonstrated by the analysis of the

\footnotetext{
23 POHLSANDER 2004, 40-47 with further bibliography.

24 On the defensive system of the Claustra Alpium Iuliarum see KOS 2012; KOS 2013; KOS 2014a; KOS 2014b.

25 BRATOŽ 2014, 108-111.

26 BRATOŽ 2014, 111-117.

27 SOTINEL 2003, 376-378; BRATOŽ 2014, 119-124.

28 RIC, VII, n. 28; BRUUN 1961, 57.

${ }^{29}$ BRUUN 1961, 103.

30 BUONOPANE/GROSSI 2014.
}

historical sources, Northern Italy played a key role for Constantine while fighting against Licinius. The same is for Aquileia, in the light of its function of logistic center for the army stationed on the Danube. Consequently, the time of Civil Wars, in particular the break between the two, saw a considerable movement of military personnel, both part of the comitatus following the emperor and the court and employed in the supply chain, between Italy and the Balkans. A new related evidence is now to be found in the hoard of nummi from Beligna. In fact its structure, as seen before an assemblage of coins directly concealed after their production, seem to be the result of a distribution of money to the soldiers. The employment of coins, including the bronze ones, in the occasion of donativa and largitiones is a well attested practice especially during the late Roman period $^{31}$. A famous testimony is represented by the treasure of precious military vestments found in Deurne, Netherlands, belonged to a member of equites stablesiani, which included also 40 Constantinian nummi ${ }^{32}$. A further documentation of coin assemblages with distinctive features found in military contexts is available. At the site of the fort Ad Statuas, west of Brigetio, a hoard of 95 bronze coins was found inside the remains of a tower, sealed under destruction layers related to a raid by the Quadi, against whom Constance II campaigned between 357-359 A.D. ${ }^{33}$. The content was exclusively made of AE3 type fel temp reparatio.FH3 from the mint of $\mathrm{Siscia}^{34}$, officinae $\mathrm{A}$ and $\Gamma$ in particular, and coins were in many cases struck from the same dies. In Augusta Raurica finds of several small hoards of die linked bronze coins, mainly produced in the mint of Lugdunum, are the result of the

31 On the system of stipendia and donativa during the time of Constantine see BASTIEN 1988; ABDY 2006, 54-55; ABDY 2012, 589-590. On the use of coins in the occasion of donativa, and especially largitiones, see MORELLI 2007; for the employment of bronze denominations BASTIEN 1988, 43-51; CHAMEROY 2004, 144-145.

32 On this find see VAN DRIEL-MURRAY 2000.

33 DUNCAN JONES 1993, 21.

34 RIC, VIII, ns. 350-351. 
supply of the troops stationed therein response to an incursion of the Alamanni in AD 351$352^{35}$. Furthermore, it must be mentioned the presence in Aquileia, even if belonging to a further stage of the Constantinian age, of two uniface gold medallions in the name of Constantine II and Constance $\mathrm{II}^{36}$, dating between 324 and $326 \mathrm{AD}$, and of two unpublished similar denominations made of silver struck in Siscia for Crispus and Constantine $\mathrm{II}^{37}$. Such artifacts was primarily conceived as decorations for the members of the regular army and of the auxiliary troops ${ }^{38}$.

The finds listed above share many numismatic features with the hoard from Beligna and all of them come from armyrelated contexts. This aspect, in conjunction with the historical and numismatic background discussed so far, constitutes a strong evidence to reconnect the assemblage of coins under investigation to a member of the Constantinian army or, in alternative, of the Imperial comitatus. This thesis is supported also by the nature of the issue VIRT EXERCIT, forming almost the entire hoard. Struck in AD 319 on a very limited scale, when Constantine was controlling the activity of the mint in Thessalonica, is characterized by a marked military iconography, depicting the Sun as the master of the army. The production of these coins was, evidently, conceived for the distribution to the troops in the occasion of an unspecified event. With some degree of certainty, is possible to assume that the owner benefited from the aforementioned donation and soon after concealed the coins once reached Aquileia, following the emperor and his court or while involved in supply duties. In alternative, in the small purse could be seen the property of a veteran who, after fighting in the Constantinian army during the Civil Wars against Licinius, choose Aquileia as new residence after leaving the military service $^{39}$. The reason for the failed recovery of

\footnotetext{
35 PETER 2011.

${ }^{36}$ ASOLATI 2012-2013, 424.

37 See ASOLATI above and RIC, VII, 716.

38 On this topic see DEPEYROT 1996; BLAND 2012.

${ }^{39}$ A famous evidence attesting the presence of veterans
}

the treasure remains obscure. As mentioned before, given the presence of a large burial site at Beligna, its destination as grave good is not to be excluded even if no archaeological evidence are available to support such reconstruction or any further conjectures.

\section{CONCLUSION}

The re-examination of the hoard find from Beligna has provided new and original data under different aspects. Firstly, it constitutes one of the greatest documentation of the nummi type VIRT EXERCIT known so far. Given a production on a very small scale, the distribution of these coins is very limited among both single and treasure finds. Furthermore, the peculiar features of this assemblage demonstrate that this issue was specifically conceived for the troops siding with Constantine the Great during the war against Licinius and his house.

A further acquisition regards the history of Aquileia during the later Empire, in particular the study of the military presence. Alongside the traditional sources, the Beligna hoard represent a unique source to trace the relationship between Constantine and the city. In fact, it witness the movement of members of his army, if not of the imperial comitatus itself, between Northern Italy and the Balkans throughout the break of the two Civil Wars. This new evidence attests the function of Aquileia as pivotal site in the struggle for power during the late Roman empire. Moreover, it reiterates the importance of the contribution of coin finds to the reconstruction of the history of the city, in some cases whit more accuracy than the traditional sources.

Lastly, the Beligna hoard represents a significant case study in which the owner of the hoard can be define with great accuracy thanks to the crossed analysis of both peculiar numismatic evidence and a well-defined historical background.

in the late Roman Aquileia is the grave stone of a member of the Moesiaci, died in 352 AD; SPEIDEL 1990, 69-72; VERGONE 2007, 291-295, n. 139; MAZZOLENI 2013, 132-133. 


\section{REFERENCES}

ASOLATI 2012-2013

Asolati, M., L'attività della zecca di Aquileia nell'età di Flavio Costantino, Aquileia Nostra 83-84, 415-431.

ABDY 2006

Abdy, R., In the pay of the Emperor: coins from the Beaurains (Arras) treasure. In: Hartley, E./Hawkes, K./Henig, M./Mee, F. (eds), Constantine and Britain (London), 52-58.

ABDY 2012

Abdy, R., Tetrarchy and the house of Constantine. In: Metcalf, W. (ed), The Oxford Handbook of Greek and Roman coinage (New York), 584-600.

BASTIEN 1988

Bastien, P., Monnaie et donativa au BasEmpire (Numismatique Romaine: Essais, Recherches, et Documentes 17, Wetteren).

BLAND 2012

Bland, R., Gold for the Barbarians? Uniface Gold Medallions of the House of Constantine Found in Britain and Ireland, Britannia 43, 217-225.

BRATOŽ 2014

Bratož, R., Costantino tra l'Italia nordorientale e l'Illirico (313-326), Antichità Altoadriatiche 78, 95-128.

BRUUN 1961

Bruun, P., Studies in Constantinian Chronology (Numismatic notes and monographs 146, New York).

BRUUN 1991a

Bruun, P., The Disappearance of Sol from the Coins of Constantine, in Studies in Constantinian Numismatics. Papers from 1954 to 1988 by Patrick Bruun (Rome, Acta Instituti Romani Finlandiae 12), 37-48 [Formerly published in Arctos 2/1958, 15-37].

BUONOPANE/GROSSI 2014

Buonopane, A./Grossi, P., Costantino, i miliari dell'Italia settentrionale e la propaganda imperiale, Antichità Altoadriatiche 78, 161-178.

BUORA 1979

Buora, M., Per la storia della Beligna e dell'Abbazia di San Martino, Aquileia Nostra 50, 445-496.

CHAMEROY 2004

Chameroy, J., La monnaie comme source historique de l'armée romaine du BasEmpire. In: Le Bohec, Y./Wolff, C. (eds), L' armée romaine de Dioclétien à Valentinien I $^{\text {er }}$ (Lyon), 139-155.

\section{CILIBERTO/VISCUSO 2015}

Ciliberto, E./Viscuso, E., Le proprietà superficiali dei nummi e le tecniche di argentatura, In: Garaffo, S./Mazza, M. (eds.), Il tesoro di Misurata (Libia). Produzione e circolazione monetaria nell'età di Costantino il Grande (Testi e Studi di Storia Antica 27, Roma), 215-226.

\section{DEPEYROT 1996}

Depeyrot, G., Les médaillons d'or unifaces du quatrième siècle (318-340), In: Hackens, T. (ed.), Italiam fato profugi hesperinaque venerunt litora. Numismatic Studies dedicated to Vladimir and Elvira Eliza Clain-Stefanelli (Numismatica Lovaniensia 12, Louvain-la-Neuve), 163-170.

DUNCAN JONES 1993

Duncan Jones, G. L., Coin circulation in the Danubian and Balkan provinces of the Roman Empire. A.D. 294-578 (Royal Numismatic Society. Special Publication 26, London).

FERRETTI/GUIDA/LASCHERA/MANDA 2015

Ferretti, M./Guida, G./Laschera, N./Manda, A., L'arricchimento superficiale nei nummi: studio degli originali e simulazioni sperimentali, In: Garaffo, S./Mazza, M. (eds.), Il tesoro di Misurata (Libia). Produzione e circolazione monetaria nell'età di Costantino il Grande (Testi e Studi di Storia Antica 27, Roma), 191-198. FMRÖ III/2

Alram, M./Schmidt-Dick, F., Numismata Carnuntina. Forschungen und material. Die antiken Fundmünzen im Museum Carnuntinum 1 (Die Fundmünzen der römischen Zeit in Österreich FMRÖ III 2, Wien 2007).

FONTANA 1997

Fontana, F., I culti di Aquileia repubblicana. Aspetti della politica religiosa in Gallia Cisalpina tra il III e il II sec. a.C. (Studi e ricerche sulla Gallia Cisalpina 9, Roma).

\section{GORINI 2015}

Gorini, G., Luisa Bertacchi ela Numismatica, Aquileia Nostra 85, 201-203.

\section{KOS 2012}

Kos, P., The construction and abandonment of the Claustra Alpium Iuliarum defence system in light of the numismatic material, Arheološki Vestnik 63, 265-300.

KOS 2013

Kos, P., Claustra Alpium Iuliarum: protecting late Roman Italy, Studia Europae Gnesnensia 7, 233-261. 
KOS 2014a

Kos, P., Construction of the Claustra Alpium Iuliarum fortifications. Historical, archaeological and numismatic sources, In: Kusetič, J. (ed.), Claustra Alpium Iuliarum - Between Research and Management (Ljubljana), 112-132.

KOS 2014b

Kos, P., Barriers in the Julian Alps and Notitia Dignitatum, Arheološki Vestnik 65, 409-422.

\section{MAGGI/ORIOLO 2012}

Maggi, P./Oriolo, F., Luoghi e segni dell'abitare nel suburbio di Aquileia, In: Bonetto, J./ Salvadori, M. (eds.), L'architettura privata ad Aquileia in età romana (Antenor Quaderni 24, Padova), 407-428.

MARANO 2009

Marano, Y., La città tardoantica. In: Ghedini, F./Bueno, M./Novello, M. (eds), Moenibus et portu celeberrima. Aquileia. Storia di una città (Roma), 23-33.

\section{MAURICE 1911}

Maurice, J., Numismatique constantinienne: iconographie et chronologie, description historique des emissions monetaries, voll. I-III (Paris).

MAZZOLENI 2013

Mazzoleni, D., L'epigrafia cristiana della prima metà del IV secolo di Aquileia, In: Tiussi, C./ Villa, L./Novello, M. (eds.), Costantino e Teodoro. Aquileia nel IV secolo, Milano, 131-137.

\section{MIRNIK 1981}

Mirnik, I., Coin hoards in Yugoslavia (BAR International series 95, Oxford).

\section{MORELLI 2007}

Morelli, A. L., La moneta nelle elargizioni pubbliche e private tra IV e VI sec. d.C. In: David, M. (ed), Eburnea diptycha. I dittici d'avorio tra antichità e medioevo (Bari), 267-295.

NURPETLIAN 2018

Nurpetlian, J., Brockage Coins, Numismatic Chronicle 178, 225-245.

\section{PETER 2011}

Peter, M., Aquileia oder Kaiseraugst? In: Ebnöther, C./Schatzmann, R. (eds), Oleum non perdidit. Festschrift für Stefanie MartinKilcher zu ihrem 65. Geburtstag, (Antiqua 47, Basel), 137-141.

POHLSANDER 2004

Pohlsander, H. A., The Emperor Constantine, second edition (London - New York).
RIC, VII

Bruun, P., The Roman Imperial Coinage, vol. 7. Constantine and Licinius, A.D. 313-337 (London 1966).

RIC, VIII

Kent, J. P. C., The Roman Imperial Coinage, vol. 8. The family of Constantine, A.D. 337364 (London 1981).

SOTINEL 2003

Sotinel, C., Aquile du Dioclétien à Théodose, Antichità Altoadriatiche 54, 375-403.

SPEIDEL 1990

Speidel, A., The army at Aquileia, the Moesiaci legion, and the shield emblems in the Notitia Dignitatum, Saalbrug Jahrbuch $45,68-72$.

\section{STELLA 2019a}

Stella, A., Too big to study? The Numismatic Collection in the National Museum of Aquileia. In: Callegher, B. (ed.), Too big to study?/Troppo grandi da studiare? (Polymnia: Numismatica antica e medievale. Studi 11, Trieste), 1-14.

STELLA 2019b

Stella, A., Aquileia tardoantica: moneta, storia ed economia, (Polymnia: Numismatica antica e medievale. Studi 13, Trieste).

THOMPSON 1954

Thompson, M., The Athenian Agora. Results of excavations conducted by the American School of Classical Studies at Athens, II, Coins from the roman through the venetian period (Princeton/New Jersey).

WEISS 2003

P. Weiss, The vision of Constantine, Journal of Roman Archaeology 16, 237-259.

VAN DRIEL-MURRAY 2000

Van Driel-Murray, C., Alate Roman assemblage from Deurne (Netherlands), Bonner Jahrbücher des Rheinischen Landesmuseums in Bonn 200, 293-308.

VERGONE 2007

Vergone, G., Le epigrafi lapidarie del Museo Paleocristiano diMonastero (Aquileia) (Antichità Altoadriatiche-Monografie 3, Trieste).

\section{VERZAR-BASS 2000}

Verzar-Bass, M., Continuità e trasformazione dei culti pagani ad Aquileia (II-IV secolo d.C.), Antichità Altoadriatiche 47, 147-174.

\section{ZACCARIA 2008}

Zaccaria, C., Cultores Beleni, In: Sartori, A. (ed.), Dedicanti e cultores nelle regioni celtiche (Quaderni di Acme 104), Milano, 375-412. 